\title{
Câmbio e crescimento
}

Luciano Nakabashi*

Existe uma relação enfatizada por alguns economistas, há algum tempo, entre crescimento econômico e saldo da balança comercial e da conta corrente. Ou seja, de acordo com essa abordagem é fundamental um bom desempenho do setor exportador de forma a manter uma conta de transações correntes equilibrada para que um determinado país consiga manter um bom nível de investimentos e de crescimento de forma sustentável.

O desempenho da balança comercial e da conta de transações correntes é relevante no montante de investimentos e no crescimento de um determinado país, pois caso se tenha uma piora na balança comercial ocorrerão efeitos contracionistas sobre os setores diretamente afetados pelo aumento das importações e/ou queda das exportações.

Outro ponto importante é que quando um país cresce com dependência de poupança externa, por um longo período de tempo, os sucessivos déficits na conta de transações correntes elevam o risco de desvalorizações cambiais até o ponto em que não vale mais a pena investir em tal região ou país. Desse modo, ocorrem ajustes através de medidas recessivas, sejam elas espontâneas ou forçadas. Ajustes forçados ocorrem através de crises de confiança com fugas de capital, grande depreciação da moeda doméstica, com uma consequente fragilidade financeira do setor público e privado, além da redução no nível de investimentos.

Finalmente, um déficit crescente na conta de transações correntes levaria o país ou região a praticar taxas de juros mais elevadas para atrair fluxos de capital, estimulando a valorização financeira do capital em prejuízo do investimento produtivo e do crescimento real da economia.

Portanto, um bom desempenho do setor exportador de forma a manter em equilíbrio o saldo da conta de transações é essencial para a manutenção de um bom desempenho econômico de forma sustentada. Adicionalmente, o crescimento sustentável das exportações, com ganhos de participação desse setor no PIB, estimula o crescimento econômico porque esse setor possui maior capacidade de absorver tecnologia do resto do

\footnotetext{
* Doutor em Economia pela Universidade Federal de Minas Gerais (UFMG). Professor do Departamento de Economia da Universidade Federal do Paraná (UFPR) e coordenador do boletim de Economia \& Tecnologia. Endereço eletrônico: luciano.nakabashi@ufpr.br.
} 
mundo e maior potencial de elevar sua produtividade quando se compara com os demais setores da economia.

No entanto, um bom desempenho do setor exportador de forma a causar sistemáticos superávits na balança comercial e na conta corrente pode levar a um processo de apreciação cambial. Este, por sua vez, além de ter impactos negativos sobre o próprio setor exportador, tende a alterar a sua estrutura produtiva, com efeitos adicionais sobre o seu desempenho. Se os setores mais prejudicados pela valorização cambial forem justamente os mais dinâmicos, os impactos sobre o crescimento de longo prazo serão negativos. Assim, o processo de valorização cambial tende a abortar o crescimento econômico tanto pelos efeitos sobre o setor externo da economia quanto pelas mudanças em sua estrutura produtiva.

Portanto, políticas econômicas que tenham como objetivo elevar o nível de investimentos e, principalmente, o crescimento da economia brasileira de forma sustentável devem se basear em medidas que estimulem o setor exportador. Outro ponto relevante é que os formuladores de política econômica precisam prestar atenção aos impactos do setor exportador sobre a taxa de câmbio real e destas no próprio setor externo da economia, no nível de investimento nos diferentes setores e no desempenho dos mesmos em termos de ganhos e perdas de participação no PIB da economia de modo a não prejudicar os setores mais dinâmicos. 